\title{
Development of B Cell Subpopulations in Humans and its Relevance to Malignancy
}

\author{
G. Janossy ${ }^{1}$, F. Caligaris-Cappio ${ }^{2}$, M. Bofill ${ }^{1}$, D. Campana ${ }^{1,2}$, and M. Janossa ${ }^{3}$
}

\section{A. Introduction}

B cell lineages are influenced by antigenindependent development and by immune activation when antigens stimulate the development of both memory B and plasma cell clones. It is difficult to investigate the origin of B cell malignancies without knowing the details of these physiological events. In 1974, Salmon and Seligmann [1] suggested that the various types of $B$ lymphoid malignancies may derive from normal cells representing different levels of maturation. In addition, the degree of differentiation which takes place within the malignant clone also seems to be variable: some malignant cells, e.g. chronic lymphocytic leukaemia (CLL), are apparently "fixed" and unable to differentiate further, while in another disease, e.g. myeloma, the lymphoid or lymphoplasmacytoid "target cells" of malignancy differentiate into plasma cells. In our study we have, therefore, decided to approach the origin of $B$ lymphoid disorders with a simple approach by asking the following questions:

1. What are the phenotypic features of $B$ lymphocytes as they emerge in the normal bone marrow (BM) during childhood? The main aim here has been to find an answer to the question whether B cell populations

1 Department of Immunology, Royal Free Hospital School of Medicine, London, NW3 2QG

2 Clinica Medica I, University of Turin, Italy

3 1st Department of Medicine, Semmelweiss University, Budapest, Hungary in the BM versus peripheral lymphoid organs have mutually distinctive features.

2. How do B cells develop in the normal fetus? Do B cells at different sites show distinct phenotypic features? In this part of the study samples of fetal BM, para-aortic lymph nodes and spleen have been studied.

3. Can B cell types (and the corresponding $B$ cell malignancies) change their features when stimulated in vitro?

There have been many previous clues about the early stages of B cell differentiation both in humans and animals (reviewed in [2, 3]). Small to medium-sized lymphoid cells with terminal transferase (TdT) enzyme activity are the likely precursors of larger pre-B cells which synthesize small amounts of cytoplasmic (Cy) $\mu$ heavy chain first, but no light chain $[4,5]$. These pre-B cells, in turn, give rise to B cells with membrane IgM, but no IgD expression, and probably also to a proportion of $\operatorname{IgM}^{+}, \operatorname{IgD}{ }^{+} B$ cells during the next stage of development $[2,6]$. But these latter cells constitute a mixture: some of them (particularly during secondary responses) appear to return to the BM from the peripheral lymphoid organs [7]. Our aim has been to establish the reactivity of these cell types using a wide range of monoclonal antibodies (MoAb) against various non-Ig membrane antigens in combination with the analysis of Ig isotype expression. Thus, the purpose of the study is to endow the hypothetical differentiation scheme with further discriminating reagents. Clearly, $\mathrm{Ig}$ isotype expression alone is not sufficient for clear discrimination; e.g. mature B cells lose $\operatorname{IgD}[6] ; \mathrm{IgM}^{+}, \mathrm{IgD}^{-}$cells, without 
further markers, cannot be affiliated to a given (early or late) maturation stage.

\section{B. Methods}

"Double-marker" methods were used with green fluorescein (FITC)- and red rhodamine (TRITC)-labelled antibodies in various combinations $[4,8]$. For example, the reactivity of $\mathrm{MoAb}$ was studied on $\mathrm{TdT}^{+}$ cells (labelled with rabbit anti-TdT) and $\mu^{+}$ as well as $\delta^{+}$B cells (labelled with an antiIgM and anti-IgD antisera, heavy chain specific, respectively). The overall proportion of $\mu^{+}, \delta^{-}$and $\mu^{+}, \delta^{+}$cells was also determined in each sample. In histology the same double-immunofluorescence technique [8] and immunoperoxidase was used together with haematoxylin counterstaining on sections of frozen biopsies.

The induction of differentiation changes using 12-O-tetradecanoylphorbol-13-acetate (phorbol ester: TPA) was an empirical method to assess links between cells expressing different phenotypes. The concentration of TPA in experiments with cell lines was $10^{-7} M$ and with leukaemic cells was $1.6 \times 10^{-8} M[9,10]$.

The samples used were from normal child BM or regenerating samples taken from cessation of chemotherapy for AML or ALL. The fetal tissues were from medically approved abortions. All suspensions, including samples from patients with chronic lymphocytic (CLL), hairy cell leukaemia (HCL) and blood samples from normal donors, were separated on Ficoll-Hypaque gradients.

\section{Results}

\section{Phenotypic Differences Between $B$ Cells in the BM and Peripheral Lymphoid Organs}

The MoAb used are shown in Table 1. The important common feature of B1, To15, RFB-4, RFB-6 and Y29/55 is that, when tested in double-marker combination with IgM in suspensions of blood and tonsil, these reagents react with $>92 \%$ of $\operatorname{IgM}^{+} \mathrm{B}$ cells. These are, therefore, pan-B reagents by these criteria. Still, when these anti- bodies were tested on BM B cells, a heterogeneity emerged which was related to the cells' Ig isotype. While the $\operatorname{IgM}^{+}, \operatorname{IgD}^{+}$cells showed the characteristic pan-B staining (>92\% $\mathrm{IgD}^{+}$cells positive) with all these antibodies, the $\operatorname{IgM}^{+}, \operatorname{IgD}^{-}$population was, in contrast, essentially negative with To15, RFB-4 and RFB-6 and had only about 50\% reactivity with $\mathrm{Y} 29 / 55$. In addition, pre-B cells and the $\mathrm{TdT}^{+} \mathrm{BM}$ precursors were also negative with this set of $B$ reagents (Table 2 ). These results can be interpreted to indicate that membrane antigens appear during B cell development in an orderly fashion. B1 is an "early marker" positive on the whole lineage starting from $\mathrm{TdT}^{+}$cells [11]. Other markers such as Y29/55 appear halfway through the generation of $\mathrm{IgM}^{+}$cells, and additional markers To15, RFB-4 and RFB-6 are expressed when $\operatorname{IgM}^{+}$cells also acquire $\operatorname{IgD}^{+}$and become functionally mature B cells. (This confirms previous results with RFA-2 and RFA-3; [12].)

There are two additional facts to support this scheme. First, another antibody, AL-1, showed a complementary pattern: strongly positive on $\mathrm{TdT}^{+}$and pre-B cells, weaker on $\operatorname{IgM}^{+}, \operatorname{IgD}^{-}$cells, but negative on the mature $\mathrm{IgD}^{+} \mathrm{B}$ cells of peripheral lymphoid tissue (Table 2). Second, the antigens To15 and RFB-4, albeit absent from the cell membrane of pre-B and $\operatorname{IgM}^{+}, \mathrm{IgD}^{-}$cells, can be found in the cytoplasm of the same cells. As Campana et al. [9] have recently shown, blast cells in fresh cases of common acute lymphoblastic leukaemia and permanent cell lines of non-T, non-B and preB type (KM3, REH and NALM-6) also show a cytoplasmic, but no membrane, expression of To15 and RFB-4. The interesting additional result is that these lines start expressing membrane Tol5 and RFB-4 when incubated with TPA for $48-72 \mathrm{~h}$. It seems therefore that not only cytoplasmic $\mu$ can change to membrane IgM during B cell development, but some other molecules also demonstrate a similar sequence of events [9].

\section{Investigations of Fetal BM}

Around the 17 th gestational week the BM contains large numbers (40\%) of lymphoid- 
Table 1. Antibodies and heterologous antisera used in this study

\begin{tabular}{|c|c|c|c|c|}
\hline Name & Source & Reactivity & $\begin{array}{l}\text { Species } \\
\text { and class }\end{array}$ & $\begin{array}{l}\text { Molecular } \\
\text { weight }\end{array}$ \\
\hline \multicolumn{5}{|l|}{ Monoclonal $A b-s$} \\
\hline AL-1 & A. M. Lebacq & Pre-B, B & Rat $\mathrm{IgG}_{2}$ & $120 \mathrm{k}$ \\
\hline BA-1 & $\begin{array}{l}\text { T. LeBien and } \\
\text { Hybritech (Cat. No. 0452) }\end{array}$ & $\begin{array}{l}\text { Pre-B, B, } \\
\text { polymorph }\end{array}$ & Mouse IgM & $30 \mathrm{k}$ \\
\hline $\begin{array}{l}\text { B1 } \\
\text { To15 }\end{array}$ & $\begin{array}{l}\text { Coulter (Cat. No. 6602140) } \\
\text { D.Y. Mason and } \\
\text { Dakopatt (Cat. No. M708) }\end{array}$ & $\begin{array}{l}\text { Few pre-B, B } \\
\text { B }\end{array}$ & $\begin{array}{l}\text { Mouse IgG } \\
\text { Mouse IgG }\end{array}$ & $\begin{array}{r}32 \mathrm{k} \\
140 \mathrm{k}\end{array}$ \\
\hline RFB4 & Royal Free Hospital & B & Mouse $\mathrm{IgG}_{1}$ & $140 \mathrm{k}$ \\
\hline RFB6 & Royal Free Hospital & B & Mouse $\mathrm{IgG}_{1}$ & $180 \mathrm{k}$ \\
\hline Y29/55 & H.K. Forster & $\mathrm{B}$ & Mouse $\mathrm{IgG}_{2}$ & \\
\hline Anti-Tac & Drs. Uchiyama \& Waldmann & IL-2 receptor & Mouse IgG & \\
\hline SHCL-3 & Dr. G. Schwarting & $\begin{array}{l}\text { Hairy cell } \\
\text { leukaemia, } \\
\text { monocytes }\end{array}$ & Mouse IgG & \\
\hline \multicolumn{5}{|l|}{ Heterologous antisera } \\
\hline Anti-Hu $\operatorname{IgM}-\mathrm{F}\left(\mathrm{ab}^{\prime}\right)_{2}$ & Kallestad (Cat. No. 140) & & Goat & $900 \mathrm{k}$ \\
\hline Anti-Hu IgD $-F\left(a b^{\prime}\right)_{2}$ & Kallestad (Cat. No. 138-148) & & Goat & $190 \mathrm{k}$ \\
\hline Anti-Ia & Royal Free Hospital & & Chicken & $28+33 \mathrm{k}$ \\
\hline Anti-TdT & $\begin{array}{l}\text { F. J. Bollum and } \\
\text { Supertech (Cat. No. 004) }\end{array}$ & & Rabbit & $67 \mathrm{k}$ \\
\hline
\end{tabular}

Table 2. The reactivity of pre-B and $B$ cells in the infant (4 samples) and regenerating bone marrow (4 samples) with B cell-specific $A b^{a}$

\begin{tabular}{|c|c|c|c|c|}
\hline \multirow[t]{2}{*}{$\mathrm{Ab}$} & \multirow[t]{2}{*}{$\mathrm{TdT}^{+}$} & \multirow[t]{2}{*}{ Pre-B } & \multicolumn{2}{|c|}{ sIgm $^{+} \mathrm{B}$ cells } \\
\hline & & & Total & $\operatorname{sIgD} D^{+b}$ \\
\hline \multicolumn{5}{|c|}{ Heterologous antisera } \\
\hline sIgD & $<1$ & $<1$ & $33 \pm 7$ & 100 \\
\hline \multicolumn{5}{|c|}{ Monoclonal antibodies } \\
\hline AL-1 & $70 \pm 5$ & $80 \pm 9$ & $83 \pm 5$ & $53 \pm 2$ \\
\hline BA-1 & $80 \pm 6$ & $98 \pm 1$ & $98 \pm 1$ & $92 \pm 3$ \\
\hline B1 & $10 \pm 2$ & $98 \pm 1$ & $97 \pm 3$ & $98 \pm 1$ \\
\hline To15 & $<1$ & $<1$ & $24 \pm 10^{c}$ & $98 \pm 1$ \\
\hline RFB-4 & $<1$ & $<1$ & $25 \pm 4^{c}$ & $94 \pm 3$ \\
\hline RFB-6 & $<1$ & $<1$ & $23 \pm 6^{c}$ & $92 \pm 4$ \\
\hline Y $29 / 55$ & $<1$ & $<1$ & $71.3 \pm 3^{c}$ & $98 \pm 0.5$ \\
\hline
\end{tabular}

a Results are expressed as percentage of cells membrane-labelled with MoAb within the given population. The ranges of these populations in the samples are: $\mathrm{TdT}^{+}$cells $0.5 \%-12 \%$; pre-B cells $\left(\right.$ cy $\left.\mu^{+}\right)$ $0.1 \%-1.5 \%$; sIgM ${ }^{+}$B cells $5 \%-10 \%$ of Ficoll-Triosil-separated cells

$b$ These cells also express IgM $\left(\mathrm{sIgM}^{+}, \mathrm{IgD}^{+}\right)$and represent a subset $(33 \% \pm 7 \%)$ of all sIgM ${ }^{+}$cells

c Within the Tol5 $5^{+}$RFB- $4^{+}, \mathrm{RFB}-6^{+}$and $\mathrm{Y} 29 / 55^{+}$populations the following percentages are $\operatorname{sIgD}^{+}: 91 \%, 85 \%, 92 \%$ and $57 \%$

d The sIgM ${ }^{+}$B cells in the fetal bone marrow at 17-20th gestational week are largely $(>90 \%) \mathrm{sIgD}^{-}, \mathrm{ALl}^{+}, \mathrm{BAl}^{+}, \mathrm{Bl}^{+}$, and $\mathrm{Tol}^{-}$, RFB4$^{-}$, RFB6 $^{-}$(see [13]) 
Table 3. B cell subpopulations in the developing human fetus ${ }^{a}$

\begin{tabular}{|c|c|c|c|c|}
\hline \multirow[t]{3}{*}{ Phenotype of relevant cells } & \multicolumn{4}{|l|}{ Gestational week } \\
\hline & \multirow{2}{*}{$\begin{array}{l}\text { Bone marrow } \\
16-22\end{array}$} & \multirow{2}{*}{$\begin{array}{l}\text { Spleen } \\
16-22\end{array}$} & \multicolumn{2}{|c|}{ Lymph node } \\
\hline & & & 16 & $17-22$ \\
\hline Precursor $\mathrm{TdT}^{+}, \mathrm{IgM}^{-}$ & $5-20$ (scattered) & $<5$ & NT & NT \\
\hline $\begin{array}{l}\mathrm{TdT}^{-}, \mathrm{IgM}^{+}, \mathrm{IgD}^{-}, \mathrm{T}^{-} \\
\mathrm{B} \mathrm{IgM}^{+}, \mathrm{IgD}^{+}, \mathrm{Tl}^{-}\end{array}$ & $\begin{array}{r}70-80 \\
2-5\end{array}$ & $\begin{array}{l}10-20 \\
80-90\end{array}$ & 95 & $\begin{array}{l}<10 \\
\text { In diffuse } \\
\text { areas }>90\end{array}$ \\
\hline $\operatorname{IgM}^{+}, \operatorname{IgD}^{+}, \mathrm{Tl}^{+}$ & $0.1-0.9$ & $1-2$ & $<5$ & $\begin{array}{l}\text { In clusters } \\
>90(\text { Fig. } 1)^{b}\end{array}$ \\
\hline $\mathrm{T}$ cells $\mathrm{IgM}^{-}, \mathrm{T1}^{+}\left(\mathrm{T}^{+},{\mathrm{T} 11^{+}}^{+}\right)$ & $\begin{array}{l}1 \%-2.5 \% \text { of mono- } \\
\text { nuclear cells }\end{array}$ & $\begin{array}{l}\text { In separate } T \\
\text { areas }\end{array}$ & $\begin{array}{l}\text { In } \mathrm{di} \\
\text { zone }\end{array}$ & $\begin{array}{l}\text { lymphoid } \\
\text { 1) }\end{array}$ \\
\hline
\end{tabular}

a The results shown refer to the percentage of cells within the B lineage (unless otherwise indicated), determined by the following labelling combinations: TdT/IgM; IgM/IgD; IgM/RFT1 (T1 antigen; $67 \mathrm{k}$ ); IgM/UCHT1 (T3 antigen; $19 \mathrm{k}$ ); IgM/RFT11 (T11 antigen; $50 \mathrm{k}$ ). In the 16-week-old LN samples only IgM/RFT1 and IgM/UCHT1 combinations were tested

b The clusters are formed around follicular dendritic reticulum cells

looking cells. Of these $15 \%-25 \%$ were $\mathrm{TdT}^{+}$ and a further $5 \%-10 \%$ were cytoplasmic $\mathrm{IgM}^{+}$pre-B cells; the majority of $\mathrm{B}$ lineage cells were membrane $\operatorname{sIgM}^{+}, \operatorname{sIgD}^{-}$B lymphocytes. It was confirmed in tissue section that these populations were indeed predominantly negative for To15, RFB-4 and RFB-6 antigens [13]. Thus, the BM B cells in the fetus represent "early" types of B cells, as expected on the basis of findings in the infant BM (Table 2).

Further studies were performed to identify the T-lineage cells in the fetal BM. Two antibodies, OKT3-like (UCH-T1) and OKT1-like (RFT1) were used, the latter in double combination with anti-IgM. T cells $\left(\mathrm{T}^{+}, \mathrm{Tl}^{+}\right)$were rare $(0.5 \%-1 \%)$ in 17 -weekold fetal BM, and these were IgM $^{-}$(Table 3 ). The proportion of $\mathrm{RFT1}^{+}, \mathrm{IgM}^{+}$doublelabelled cells was very low: $0.1 \%-0.9 \%$ amongst the $\mathrm{IgM}^{+}$population $(0.02 \%$ $-0.15 \%)$ of all BM cells. This contrasts with the findings observed in fetal lymph nodes (see Sect. C.IV).

\section{Analysis of Fetal Spleen}

In the samples of fetal spleen taken at the 18th gestational week 4-5 times more B cells were found than $T$ cells. Of all cells,
$4 \%-6 \%$ were $\operatorname{IgM}^{+}$and another $1 \%-2 \%$ $\mathrm{T}^{+}$. The $\mathrm{T}$ cell population was clustered around small blood vessels, and the B cells formed a loose band of cells at the edge of the splenic red pulp. No follicular dendritic reticulum cells were seen.

There were two important findings about the splenic B cells. First, these splenic B cells have clearly shown a "peripheral B cell" phenotype: $80 \%-90 \%$ were $\mathrm{IgM}^{+}$, $\mathrm{IgD}^{+}$and virtually all (>95\%) B cells clearly reacted with MoAb RFB-4, To15 and RFB-6. On the other hand, we could not observe significant numbers of $\operatorname{IgM}^{+}, \operatorname{IgD}^{-}$ $B$ cells. This is interesting because in the adult human (and rat) spleen a clearly visible population of $\mathrm{IgM}^{+}, \mathrm{IgD}^{-}$cells is present in the marginal zone [14], but these are probably mature cells in a relatively late stage of development. Second, immunohistological techniques were used to identify B cells expressing $\mathrm{T}$ cell-associated markers such as T1 and only a few $\left(1 \%-2 \%\right.$ of IgM $^{+}$ cells) appeared to express the $\mathrm{T} 1$ antigen (Table 3) up to the 23 rd week when more $\mathrm{Tl}^{+}, \mathrm{IgM}^{+}$cells appeared [13].

\section{Analysis of Fetal Lymph Nodes}

In the earliest lymph nodes found (at 16th gestational week) $T$ and $B$ cell areas were 



Fig. 1A, B. B lymphocytes within the primary lymphoid nodules of fetal lymph nodes (20th gestational week) show double staining for IgM (A) and the $\mathrm{T}$ cell-associated antigen $\mathrm{Tl}$ (B). These B cells are accumulating around dendritic reticulum cells [13]. The rare $\mathrm{B}$ cells diffusely distributed in the paracortical $\mathrm{T}$ area are strongly $\mathrm{IgM}^{+}$and $\mathrm{Tl}^{-}$(arrows). This $\mathrm{B}$ cell population is dominant in the fetal spleen (Table 2; [13])

not yet separated. T lymphocytes $\left(\mathrm{T}^{+}, \mathrm{T3}^{+}\right)$ as well as the $\mathrm{IgM}^{+} \mathrm{B}$ cells $(30 \%$ of lymphocytes) were diffusely mixed. No $\mathrm{Tl}^{+}, \mathrm{IgM}^{+}$double-labelled cells were seen. In the lymph node samples taken at 18 th week tight clusters of lymphocytes appeared accumulating 100-200 cells around follicular dendritic cells (FDR cells; identified by RFD-3 antibody) and uniformly showed a peculiar phenotype. All these cells were $\operatorname{IgM}^{+}, \mathrm{IgD}^{+}$(moderately strongly), expressed BA-1 positivity and reacted with RFB-4, To15 as well as RFB-6 (B cells of peripheral type). In addition, the $\mathrm{B}$ cells in the clusters were invariably $\mathrm{T1}^{+}$ (moderately strongly; Fig. 1) but HLA-DR positive and $\mathrm{T} 3$ negative. The $\mathrm{T}$ lymphocytes $\left(\mathrm{T}^{+}, \mathrm{Tl}^{+}, \mathrm{HLA} \mathrm{DR}^{-}, \mathrm{IgM}^{-}\right)$were found in the diffuse lymphoid area and showed a much stronger $\mathrm{Tl}^{+}$staining. Finally, it is important to point out that within the small B lymphoid follicles no large germinal centre blasts were seen, and the $\mathrm{BA}-1^{-}$, weak $\mathrm{IgM}^{+}, \mathrm{IgD}^{-}$central population seen in the germinal centres of adult lymph nodes were absent.

\section{Malignant B Cells}

$\mathrm{TdT}^{+}$cells are present in large proportions amongst the lymphoid cells of fetal liver $[11,15]$ and fetal BM [13, 15]. These cells lack a number of other B cell markers such as Y29/55 [16], RFB-6, or show only cytoplasmic, but no membrane expression of RFB-4 or To15. The phenotypic features of these $\mathrm{TdT}^{+}$cells are similar to the blast cells seen in common acute lymphoblastic (cALL) and pre-B ALL [9, 11, 15-17].

As we recently emphasized [13], the $\mathrm{T1}^{+}, \mathrm{IgM}^{+}, \mathrm{IgD}^{+}$cells with peripheral B cell features $\left(\mathrm{Y}^{2} 2 / 55^{+}, \mathrm{RFB}-6^{+}, \mathrm{RFB}-4^{+}\right.$, 


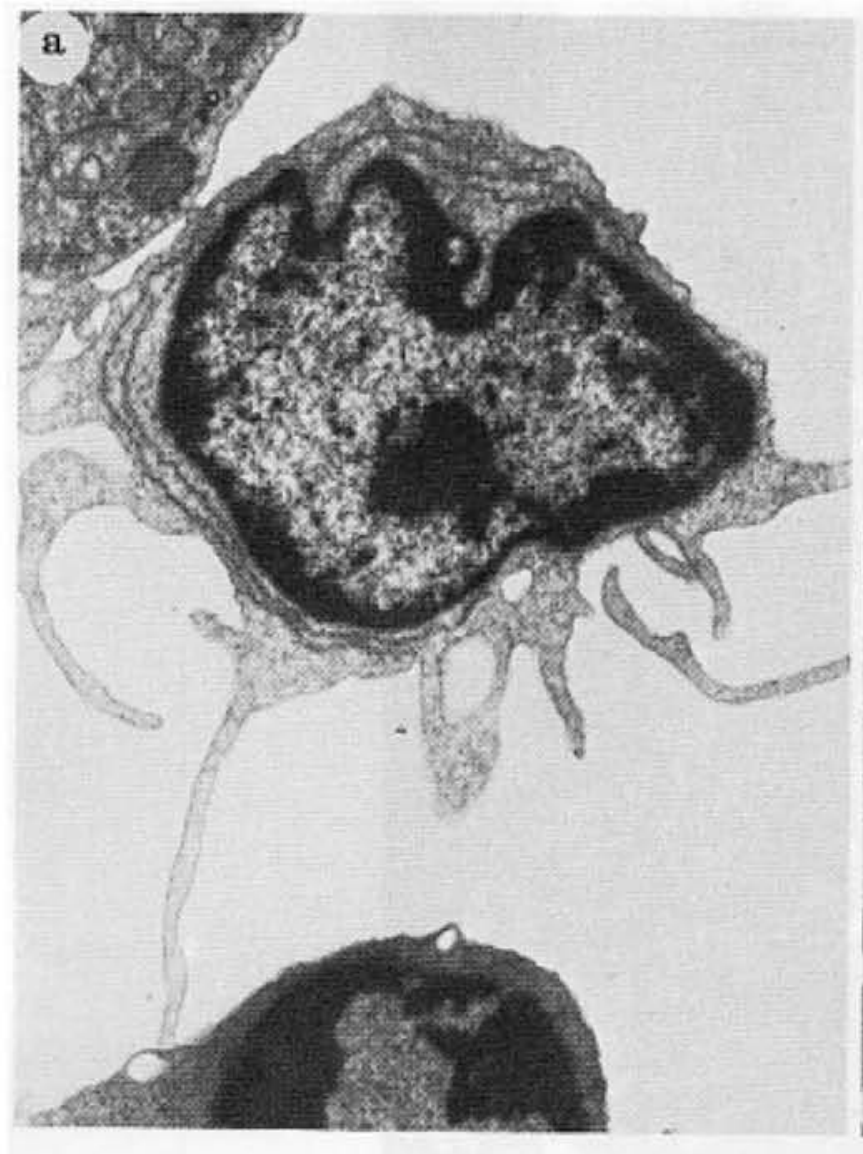

Fig. 2a-c. B-CLL cells after $72 \mathrm{~h}$ TPA stimulation develop "hairs" $(\mathrm{a} \times 10000)$. Cells in the control unstimulated B-CLL culture have smoother surface $(b \times 6000)$ and normal B cells in the presence of TPA also remain smooth (not shown; but see [23]). For comparison hairy cell leukaemia is shown $(c \times 8000)$. From [10] with permission

To15 ${ }^{+}$) which cluster around follicular dendritic reticulum cells in fetal lymph nodes (see Sect. C.IV) are very similar, by phenotypic criteria, to two B cell malignancies: centrocytic lymphoma [18] and B-type chronic lymphocytic leukaemia (BCLL; [19]). The further distinctive phenotypic features of these malignancies are the reactivity of Tü-33 Mo-Ab with centrocytic lymphoma and that of Tü-1 $\mathrm{Ab}$ with B-CLL [18]. Indeed, the normal equivalent $\mathrm{T1}^{+}, \mathrm{IgM}^{+}$cells in the primary nodules of normal fetal LN samples are also heterogeneous in respect of Tü-33 and Tü-1 expression [13]. Thus, centrocytic lymphoma and B-CLL might originate from the Tü$33^{+}$and $\mathrm{Tü}-1^{+} \mathrm{B}$ cells of primary nodules, respectively.

The exact origin of hairy cell leukaemia (HCL) is nevertheless still unknown. This

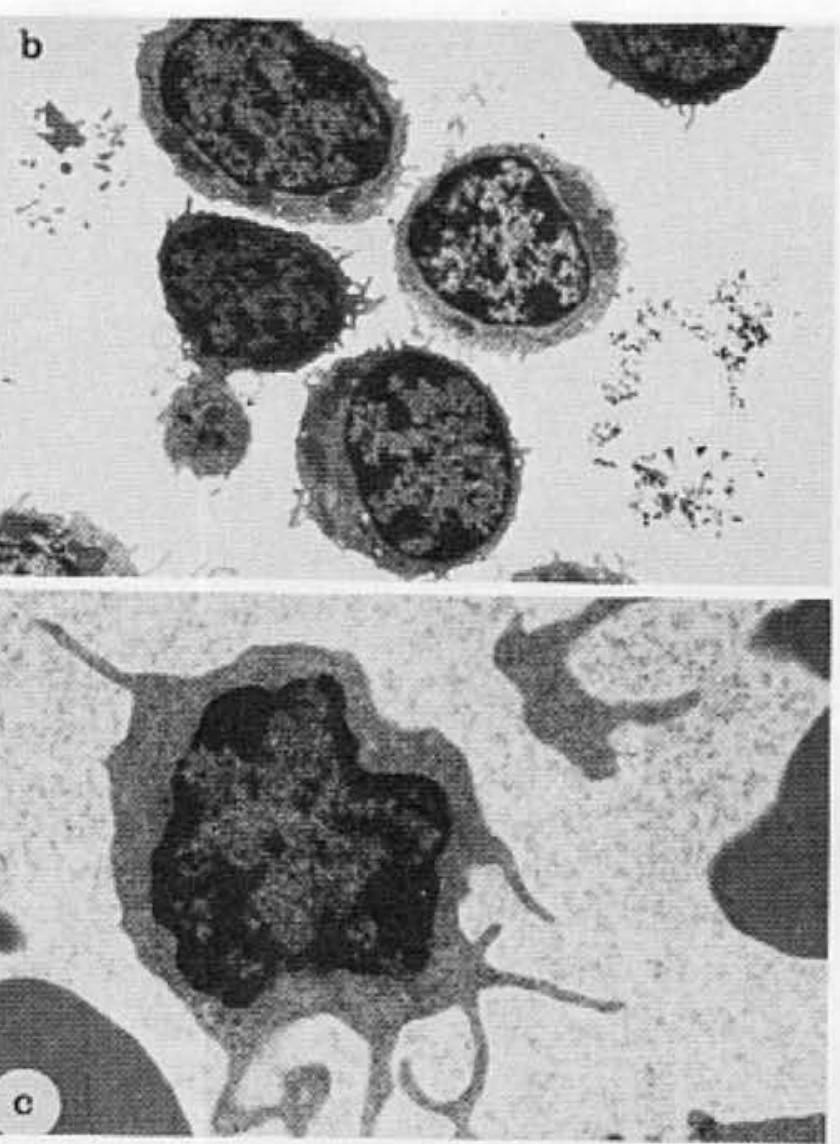

disease, in its typical form, is a B cell malignancy with the following features: (a) SmIg expression and Ig gene rearrangements [20]; (b) characteristic membrane protrusions and veils; (c) strong cytoplasmic tartrate-resistant acid phosphatase activity (TRAP; [21]); (d) reactivity with MoAb to interleukin-2 receptor (anti-Tac; [20]); and (e) reactivity with MoAb to SHCL3 antigen, a membrane moiety not expressed by B-CLL [22]. As the "normal equivalent" cell of HCL has so far been elusive, we have investigated whether any known malignant $\mathrm{B}$ cells can be transformed into HCL. The details will be published elsewhere [23] and the salient observations are as follows.

First, it has been observed that the expression of TRAP enzyme activity can be readily induced by TPA in normal tonsil B cells and their mouse rosetting subset [23] during a $72-\mathrm{h}$ culture period $(60 \%$ and $18 \%$ positivity, respectively). A few SHCL3-positive B cells were also generated in the same cultures (25\% and $7 \%$, respectively). Only very few $\mathrm{Tac}^{+} \mathrm{B}$ cells were seen, however, and these were best generated in 6- or 7-day cultures stimulated by PWM $\left(\mathrm{Ig}^{+}\right.$ blasts; $\left.5 \% \mathrm{Tac}^{+}\right)$. Thus, with the possible 
Table 4. TPA-induced changes in B-chronic lymphocytic leukaemia (B-CLL) and hairy cell leukaemia $(\mathrm{HCL})^{\mathrm{c}}$

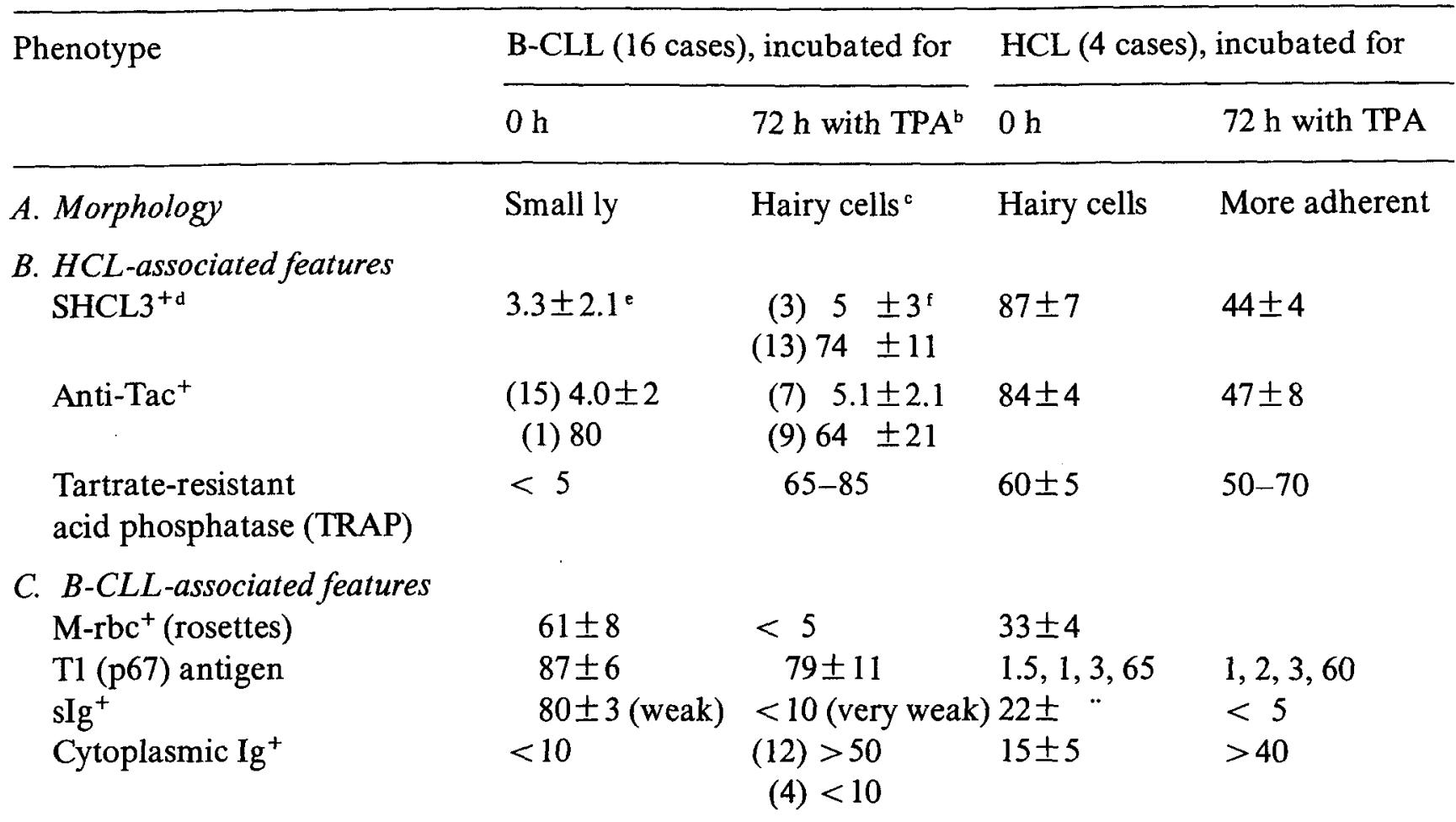

a 16 cases of B-CLL and 4 cases of HCL were studied. There has been no change in the features of B-CLL and HCL cultures for $72 \mathrm{~h}$ without TPA (except a slight decrease in M-rbc rosetting). For further details see [23]

b TPA (12-O-tetradecanoylphorbol-13-acetate) was used for $72 \mathrm{~h}$ at $1.6 \times 10^{-8} M$ concentration

c See Fig. 2

d A MoAb from Dr. Schwarting [22]

e Percentage ( \pm standard error) of cells reacting with each marker

f Numbers in parentheses refer to numbers of cases

exception of membrane irregularities, the features of HCL are not fully leukaemia specific. Next, various leukaemias were "induced" by TPA. These included 16 cases of B-CLL $\left(\mathrm{Tl}^{+}, \mathrm{sIgM}^{+}\right.$, weak), 4 cases of prolymphocytic leukaemia and "mantle zone" lymphoma (strongly $\mathrm{Ig}^{+}$positive; $\mathrm{Tl}$ mostly negative) and 2 cases of common ALL $\left(\mathrm{TdT}^{+}, \mathrm{sIg}^{-}\right)$.

We have reported previously that TPAinduced B-CLL cells developed membrane perturbations characteristic of hairy protrusions (Fig. 2; [10]). Clearly, other "HCLassociated" features could also be observed in the majority of cases. Of 16 cases, 13 had $>50 \%$ SHCL $^{+}$cells, and 9 showed strong Tac positivity in $64 \% \pm 21 \%$ of activated B-CLL cells; $60 \%-85 \%$ of cells were TRAP ${ }^{+}$ (Table 4). These "HCL-like" features on activated B-CLL cells were much stronger than on any of the TPA-activated normal B cell populations, including the mouse rosetting subpopulation. Similar HCL-like features (e.g. membrane irregularities and SHCL3 positivity) have not been recorded in the other leukaemias, although cases of PLL and mantle zone lymphoma did develop Tac positivity $(45 \%-80 \%$; results not shown, but see [23]). Finally, cases of HCL (four patients) when activated with TPA, did not show major phenotypic changes, and have not developed CLL-like features [23].

\section{Discussion}

The two main findings about emerging $B$ cells during fetal development are that: (a) the "early" $B$ cells (pre-B and $\operatorname{IgM}^{+}, \operatorname{IgD}^{-} \mathrm{B}$ ) 

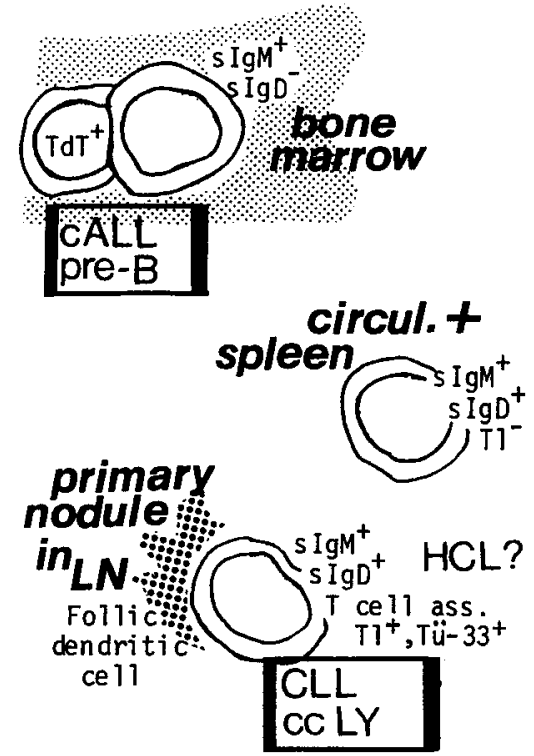

Fig. 3. The three main B cell types observed in the fetus. In the bone marrow pre-B and B cells are $\mathrm{IgM}^{+}, \mathrm{IgD}^{-}, \mathrm{AL}-1^{+}$and do not express membrane RFB-4, To15, RFB-6. On the periphery strongly $\mathrm{Ig}^{+}\left(\mathrm{IgM}^{+}, \mathrm{IgD}^{+}\right)$cells circulate in blood and are seen in the spleen while $B$ cells in the primary nodules in the lymph node show weaker $\mathrm{IgM}^{+}$and $\mathrm{IgD}^{+}$and express $\mathrm{T}$ cell-associated antigen such as $\mathrm{Tl}$ and Tü-33. For further details see also $[9,13]$

in fetal bone marrow are different, by a number of criteria, from peripheral B cells [9]; and (b) there is a dichotomy amongst the peripheral B cell populations [13]. This leads to emphasizing the existence of three major B cell types in the fetus: one in the $\mathrm{BM}$, and two in the periphery (Fig. 3). To this heterogeneity further forms (e.g. germinal centre blasts, and plasma cells) are added when the individual is exposed to extrinsic antigens during later life. This scheme is similar to those presented by Galton and MacLennan [14] and also indicated by Stein et al. [18] on the basis of lymphoma heterogeneity. Indeed, the new findings here support the existence of normal B cells (most probably virgin peripheral B lymphocytes of primary lymphoid nodules) which express some $\mathrm{T}$ cell-associated markers such as $\mathrm{T} 1$ and Tü-33. These B cells are also present in adults [19], but only in smaller numbers, perhaps because they are "diluted out" by other newly emerging cell types.

The finding of $\mathrm{IgM}^{+}, \mathrm{T1}^{+}$normal B cells in the primary nodules may explain two unrelated puzzling phenomena. First, certain $B$ cell malignancies express $T$ cell-associated features with some regularity. The $\mathrm{T} 1$ antigen on $\mathrm{B}-\mathrm{CLL}, \mathrm{T} 1$ plus Tü-33 on centrocytic lymphoma (Kiel classification; [18]) are the obvious examples (see Sect. C.), but T3 as well as T11 molecules were also seen in a few cases of B-CLL and B lymphomas, in spite of the fact that these showed monoclonal ( $x$ or $\lambda$ ) light chain, IgM as well as HLA-DR [24-27]. Similarly, Cawley et al. [28] have emphasized that $\mathrm{HCL}$ were capable of expressing $\mathrm{T}$ cell features (sheep erythrocyte rosetting) during certain stages of disease progression. The derepression of $\mathrm{T}$ cell genes may be more frequent in the recently identified $\mathrm{T}^{+}, \mathrm{IgM}^{+}$cells or their malignant counterparts than in the other B cell subsets.

At least a subgroup of $\mathrm{HCL}$ might also be related to the B-CLL group. This is indicated by the observations of "inducing" HCL-like features in B-CLL cells with TPA (Table 4). Taken at face value, these results and those described by Caligaris-Cappio $[10,23]$ show that TPA-induced B-CLL and HCL both have abnormal membrane characteristics in terms of "hair" formation, which is not demonstrated in the equivalent normal cells. In other respects, HCL appears to be an activated variant of B-CLL or that of a closely related cell type. An alternative explanation is that the HCLassociated markers (Tac expression, TRAP and SHCL3 positivity) are nonspecific features which appear on unrelated B cell types. Clearly, more work is needed in this area, but it is already clear that other B cell malignancies such as prolymphocytic leukaemia, mantle zone lymphoma and pre-B ALL (and the corresponding cell lines) do not develop HCL-like features when induced by TPA [23]. Thus, the CLL-HCL link has so far appeared to be a rather special one. The possibility of the CLL-HCL link is also supported by the existence of leukaemias showing circulating HCL together with B-CLL-like histological pattern [29, 30].

Second, it has been demonstrated in the mouse that $\mathrm{Ly}-1^{+}, \mathrm{IgM}^{+} \mathrm{B}$ cells are also present and, in the NZB strain, contribute to autoantibody synthesis [31]. The observation of frequent autoantibody forma- 
tion in B-CLL [32] raises the possibility that in these patients the whole $\mathrm{T}^{+}, \mathrm{IgM}^{+}$lineage is hyperactive and the monoclonal malignancy might be just one of the later, although dramatic, consequences of this dysregulation. This is an interesting possibility from the point of view of preventing a malignant disease. Similarly, further studies are necessary to investigate this B cell population in autoimmune disorders. It will be interesting to see whether the increased numbers of circulating mouse rosetting B cells in rheumatoid arthritis [33] also show the $\mathrm{Tl}^{+}, \mathrm{IgM}^{+}$phenotype.

Acknowledgements. This work was supported by the Leukaemia Research Fund of Great Britain (G.J. and D.C.) by PFCCN-CNR of Italy (F.C.C. Grant No. 830075296) and by an Armour Pharmaceutical Scholarship (M.B.). We ware grateful to Dr. M. Chilosi, Verona, for TRAP staining and to Dr. G. Schwarting, Berlin, for SHCL3 antibody.

\section{References}

1. Salmon SE, Seligmann M (1974) B cell neoplasia in man. Lancet 2:1230-1233

2. Vogler LB (1982) Bone marrow B development. Clin Haematol 11:509-529

3. McKenzie IFC, Zola H (1983) Monoclonal antibodies to $B$ cells. Immunol Today 4: $10-14$

4. Janossy G, Bollum FJ, Bradstock KF, McMichael A, Rapson N, Greaves MF (1979) Terminal transferase positive human bone marrow cells exhibit the antigenic phenotype of common acute lymphoblastic leukemia. J Immunol 123: 1525-1529

5. Gathings WE, Lawton AR, Cooper MD (1977) Immunofluorescent studies of the development of pre-B cells, B lymphocytes and immunoglobulin isotype diversity in humans. Eur J Immunol 7:804-810

6. Moller G (ed) (1977) Immunoglobulin D: structure, synthesis, membrane representation and function. Immunol Rev 37

7. Benner R, Hijmans W, Haaijman JJ (1981) The bone marrow: the major source of serum immunoglobulins, but still a neglected site of antibody formation. Clin Exp Immunol 46:1-8

8. Janossy G, Thomas JA, Bollum FJ, Granger S, Pizzolo G, Bradstock KF, Wong L, Ganeshaguru K, Hoffbrand AV (1980) The human thymic microenvironment: an immunohistological study. J Immunol 125:202-212
9. Campana D, Janossy G, Bofill M, Trejdosiewicz LK, Ma D, Hoffbrand AV, Mason DY, Lebacq A-M, Forster H (1985) Human $B$ cell development. I. Phenotypic differences of B lymphocytes in the bone marrow and peripheral lymphoid tissue. J Immunol 134:1524-1529

10. Caligaris-Cappio F, Janossy G, Campana D Chilosi M, Bergui L, Foa R, Delia D, Giubellino MC, Preda P, Gobbi M (1984) Lineage relationship of chronic lymphocytic leukaemia and hairy cell leukaemia: studies with TPA, Leuk Res 8:567-578

11. Hokland P, Rosenthal P, Griffin J, Nadler L, Daley J, Hokland M, Schlossman SF, Ritz J (1983) Purification and characterization of fetal hematopoietic cell that express the common acute lymphoblastic leukaemia antigen (CALLA). J Exp Med 157: 114-129

12. Gobbi M, Caligaris-Cappio F, Janossy $G$ (1983) Normal equivalent cells of B cell malignancies: analysis with monoclonal antibodies. Br J Haematol 54:393-403

13. Bofill M, Janossy G, Janossa M, Burford GD, Seymour GJ, Wernet P, Kelemen E (1985) Human B cell development. II. Subpopulations in the human fetus. J Immunol 134: $1530-1537$

14. Galton DAG, MacLennan ICH (1982) Clinical patterns in B lymphoid malignancy. Clin Haematol 11:561-587

15. Bodger MP, Janossy G, Bollum FJ, Burford $\mathrm{GD}$, Hoffbrand AB (1983) The ontogeny of terminal deoxynucleotidyl transferase. Blood 61:1125-1131

16. Hirt A, Baumgartner C, Forster HK, Imbach P, Wagner HP (1983) Reactivity of acute lymphoblastic leukemia and normal bone marrow cells with the monoclonal antiB-lymphocyte antibody, anti-Y29/55. Cancer Res 43:4483

17. Nadler LM, Anderson KC, Marti G, Bates M, Park E, Daley JF, Schlossman SF (1983) Human B lymphocyte-associated antigen expressed on normal mitogen-activated and malignant B lymphocytes. J Immunol 131: 244-258

18. Stein H, Gerdes J, Mason DY (1982) The normal and malignant germinal centre. Clin Haematol 11:531-559

19. Caligaris-Cappio F, Gobbi M, Bofill $M$, Janossy $G$ (1982) Infrequent normal B lymphocytes express features of B-chronic lymphocytic leukaemia. J Exp Med 155:623-628

20. Korsmeyer SJ, Hieter PA, Ravetch JV, Poplack DG, Waldmann TA, Leder P (1981) Developmental hierarchy of immunoglobin gene rearrangements in human leukaemic pre-B cells. Proc Natl Acad Sci USA 78:7096-7100 
21. Ly CY, Yam LT, Lam KW (1970) Acid phosphatase isoenzyme in human leucocytes in normal and pathologic conditions. $J$ Histochem Cytochem 18:473

22. Schwarting G, Stein H (1985) Reactivity of SHCL3 antibody (in press)

23. Caligaris-Cappio F, Pizzolo G, Chilosi M, Bergui L, Campana D, Morittu L, Gobbi G, Janossy G (1985) Phorbol ester induces abnormal CLL cells to express features of hairy cell leukaemia. Blood (in press)

24. Aisenberg AC, Bloch KC, Wilkes BM (1981) Malignant lymphoma with dual $B$ and $T$ cell markers. Analysis of neoplastic cells with monoclonal antibodies directed against $\mathrm{T}$ cell subsets. J Exp Med 154: 1709-1714

25. Habeshaw JA, Bailey D, Stansfeld AG, Greaves MF (1983) The cellular content of non-Hodgkin lymphomas: a comprehensive analysis using monoclonal antibodies and other surface marker techniques. Br J Cancer 7:327-351

26. Schroff RW, Foon KA (1982) Heterogeneity in a lymphoid tumour: co-expression of $\mathrm{T}$ and $B$ markers. Blood 60:373-380
27. Sitia R, Sciariada L, Zicca A, Leprini A, Ghio R, Ferrarini M (1983) Expression of a receptor for sheep erythrocytes by B lymphocytes from a CLL patient. Clin Immunol Immunopathol 27:210-222

28. Cawley JC, Burns GF, Nash TA et al. (1978) Hairy cell leukaemia with $T$ cell features. Blood 51:61-69

29. Palatke M, Tabaczka P, Mirchandani I, Goldfarb S (1981) Lymphocytic lymphoma simulating hairy cell leukaemia. Cancer 48:2047

30. Neiman RS, Sullivan AL, Jaffe R (1979) Malignant lymphoma simulating leukemic reticuloendotheliosis. Cancer 43:329

31. Hayakawa K, Hardy RP, Parks DR, Herzenberg LA (1982) The "Ly-1 B" cell subpopulation in normal, immunodefective and autoimmune mice. J Exp Med 157:202-220

32. Seligmann M (1984) Human lymphocyte subsets in health and disease. Prog Immunol 5: 1047-1051

33. Room GRW, Plater-Zyberk C, Maini RN (1983) Mouse rosetting cells in rheumatoid arthritis. Rheumatol Int 23:141 